\title{
COVID-19 Shows the Need for a Global Animal Law
}

\author{
Anne Peters \\ Director at the Max Planck Institute for Comparative Public Law and International Law, Heidelberg \\ (Germany) \\ Professor at the University of Heidelberg, Freie Universität Berlin, and Basel, and a L. Bates Lea Global \\ Law professor at the Law School of the University of Michigan. \\ https://orcid.org/0000-0002-2779-0626
}

Cita recomendada. PETERS, A., COVID-19 Shows the Need for a Global Animal Law, dA. Derecho Animal (Forum of Animal Law Studies) 11/4 (2020). - DOI https://doi.org/10.5565/rev/da.510

\begin{abstract}
The pandemic COVID-19 - which is a zoonosis - illustrates how problems of global nature and proportions stem from human use and abuse of animals and therefore underlines the necessity of a global law approach. The social, ecological, and economic consequences of animal exploitation, notably (but not limited to) agriculture, range from human poverty to transnational organised wildlife crime, to global warming, and of course to animal suffering. Not the least, the danger of the outsourcing of animal-processing industries and research facilities to animal cruelty havens and the threat of a regulatory chill on the national level suggest that the regulatory response to animal issues needs to be global. The Office International des Epizooties (OIE) could be transformed into the institutional hub for such an approach. The contribution also addresses and refutes the challenge of cultural and legal imperialism that is mounted against such a global law approach. It suggests to develop further the One Health paradigm for containing the pandemic and for combatting future zoonoses. The paper concludes that a critical global animal law approach will be helpful for overcoming the COVID-crisis and is generally warranted for transforming human-animal interaction.
\end{abstract}

Key words: animal rights; animal welfare; zoonosis; World Organisation for Animal Health; Office International des Epizooties; globalisation; regulatory chill; Islamabad High Court; One Health.

Resumen - El COVID-19 pone de manifiesto la necesidad de un Derecho Animal Global

La pandemia de COVID-19 - una zoonosis - ilustra cómo los problemas de naturaleza y proporciones mundiales se derivan del uso y abuso de animales por parte de los humanos y, por lo tanto, subraya la necesidad de un enfoque jurídico global. Las consecuencias sociales, ecológicas y económicas de la explotación animal, en particular (pero no solamente) la agricultura, van desde la pobreza humana hasta los delitos transnacionales organizados contra la vida silvestre, el calentamiento global y, por supuesto, el sufrimiento de los animales. No menos importante, el peligro de la subcontratación de las industrias de producción de animales y las instalaciones de investigación para los paraísos de crueldad animal y la amenaza de un enfriamiento normativo a nivel nacional sugiere que la respuesta normativa a los asuntos sobre los animales debe ser global. La Organización Mundial de Sanidad Animal (OIE) podría transformarse en el centro institucional para este enfoque. La contribución también aborda y refuta el desafío del imperialismo cultural y legal que se desarrolla contra un enfoque de derecho global como este. Se sugiere desarrollar aún más el paradigma "Una Sola Salud" (One Health) para contener la pandemia y combatir futuras zoonosis. El artículo concluye que un enfoque crítico de derecho animal global sería de ayuda para superar la crisis de 
COVID y, en general, está justificado para transformar la interacción humano-animal.

Palabras clave: derechos de los animales; bienestar animal; Organización Mundial de Sanidad Animal; Office International des Epizooties; globalización; enfriamiento normativo; Tribunal Superior de Islamabad; Una Sola Salud.

\section{Introduction}

Germs and microbes do not respect borders. This also applies to viruses causing illness in non-human and human animals and spreading from the one to the other. COVID-19 is such a disease, a zoonosis. It is so far unknown whether this novel virus originated from the wild animal market in Wuhan or from the bat laboratory next to the market. But it has obviously come upon us as a result of human use and abuse of animals. The zoonotic pandemic can only be addressed by relying on a global law approach and thus illustrates the need for building up the fairly novel discipline of global animal law.

Section 2 discusses two current cases which illustrate the shared vulnerability of human and non-human animals towards the new virus. Section 3 suggests that the World Organisation for Animal Health (OIE) be built up as the institutional hub for combatting zoonoses, in collaboration with other international organisations. Section 4 explains that the current human-animal interactions cause problems of a global nature and proportions, ranging from environmental to climatic, social, and security threats. The globalised nature of the issue is additionally shaped by the mobility of production factors in the interconnected animalrelated economy which leads to outsourcing and regulatory competition on a global scale. Section 5 addresses the danger of a Western cultural and legal imposition of prescriptions on the treatment of animals and concludes that an overlapping consensus on the relevant questions can be formed. Section 6 discusses how COVID-19 calls for an intensification and adaptation of the One Health approach for tackling this and also foreseeable future zoonoses. The concluding section 7 recalls the ambivalence of the law which both harms and protects animals and demands a critical sensibility in developing the field of global animal law.

\section{Shared Vulnerability in the Era of COVID-19}

\section{1. "One Life": The Islamabad Zoo and the Lockdowns}

Human and non-human animals share the vulnerability against COVID-19. The Islamabad High Court emphasised this aspect in a recent decision which recognised the right to life of captured zoo animals ${ }^{1}$. The Court pointed out that the petitions (which had demanded the release of the neglected animals) have "a nexus with the threat to human existence highlighted by the current pandemic crisis." This crisis "has highlighted the interdependence of living beings on each other, (...) and (...) it has conspicuously brought the essence, meaning and significance of 'life' into the spotlight." The Court compared the spring lockdowns for humans to the confinement of zoo animals: "Billions across the globe have voluntarily gone into 'captivity' fearing death and illness" 2 "The arrogance of being superior to other living beings seems to have been forgotten in the face of the threat of an invisible and hitherto unknown enemy" 3 .

The Court concluded that the right to life as guaranteed in the Constitution of Pakistan is incumbent not only to humans, but that also nonhuman animals possess a constitutional right to life. Based on this argument, the Court ordered that a board constituted under the state's Wildlife Ordinance should relocate all the animals (an Asian elephant, bears, a marsh crocodile, and others), to sanctuaries.

\section{2. "One Death": Men and Minks}

The shared vulnerability against COVID-19 materialised in mink farms in the Netherlands. In this country, 128 farms held 4.5 million minks. In the spring and summer of 2020, more than 1.1 million of the animals were culled in more than 20 plants, because they were struck by COVID-194 ${ }^{4}$ Probably, the minks

\footnotetext{
${ }^{1}$ Islamabad High Court, ISLAMABAD (JUDICIAL DEPARTMENT) W.P. No.1155/2019 Islamabad Wildlife Management Board through its Chairman v. Metropolitan Corporation Islamabad through its Mayor \& 4 others, judgment of 21 May 2020.

${ }^{2}$ Ibid., p. 2.

${ }^{3}$ Ibid.

${ }^{4}$ ZDF Nachrichten, Wissenschaftler alarmiert: Corona-Ausbrüche in Nerzfarmen.
} 
had been infected by a human labourer on one of the farms, and the minks then transmitted COVID-19 back to other human workers. Although the exact ways of transmission are not fully known, it is clear that a mink-human transmission took place in whatever direction, as the WHO confirmed ${ }^{5}$. The episode sped up the phasing-out of the mink farms in the Netherlands. Parliament adopted a law prohibiting the business, coupled with financial compensation of the fur-farmers ${ }^{6}$.

In Denmark, which produced 17 million mink pelts per year, a novel variant of COVID-19 broke out, infecting at least 214 humans and uncounted minks. This led to the immediate culling of all animals in the fall of $2020^{7}$.

The interdependence of human and mink health led to an outcome that was - unlike in the Islamabad case - not good for the animals. More than 20 million minks were killed. So indeed, the vulnerability is shared. But power and means to exercise deadly force remain unequally distributed among humans and animals - also in times of COVID-19.

\section{The Institutional Hub for Combatting Zoonoses}

Of course COVID-19 is not the first instance of human-animal contamination. Actually, the spread of a zoonosis, transmitted from African gazelles which were shipped to America through the port of Antwerp, had triggered the creation of one of the first international organisations and the only one dedicated to animal health and welfare so far. It is the Office International des Epizooties, English: World Organisation for Animal Health (OIE), with its seat in Paris. This inter-governmental organisation was founded in 1924 by 28 states $^{8}$ and now counts 182 member states. The organisation's original mandate concerned mainly "research or investigation concerning the pathology or prophylaxis of contagious diseases of animals which call for international collaboration" and "veterinary police measures" 9 . Since then, the organisation has evolved significantly. It notably extended its mandate in 2002 from animal health to include animal welfare ${ }^{10}$. The organisation today describes itself as "the key international organisation for animal welfare" ${ }^{\text {"11 }}$. Since then, the OIE has unfolded a wide range of activities for the promotion of animal welfare. It has adopted an animal welfare strategy, and so far three general "animal welfare" resolutions ${ }^{12}$. The organisation also entertains an Animal Welfare Fund which is mainly financed by the EU.

The OIE is also a reference organisation for the development and harmonisation of international standards, guidelines, and recommendations on animal health within the framework of the Agreement on Sanitary and Phytosanitary measures (the SPS-Agreement) under the auspices of the World Trade Organisation ${ }^{13}$. As it is well known, the OIE has elaborated animal welfare standards. These are included as

https://www.zdf.de/nachrichten/panorama/coronavirus-infektion-ausbrueche-nerzfarmen-100.html [Last accessed: 12 November 2020].

${ }^{5}$ See on SARS-CoV-2 (which leads to the disease called COVID-19) on mink farms: BAS B. OudE MunNINK et al, Jumping back and forth: Anthropozoonotic and zoonotic transmission of SARS-CoV-2 on mink farms. doi: https://doi.org/10.1101/2020.09.01.277152 (preprint in biorxiv). See for the political level: WHO, Covid 19-Virtual Press Conference of 22 June 2020. See also Statement of the Dutch government of 19 May 2020: New results from research into COVID-19 on mink farms. https://www.government.nl/latest/news/2020/05/19/new-results-from-research-into-covid-19-on-mink-farms [Last accessed: 12 November 2020].

${ }^{6}$ Tweede Kamer der Staten-Generaal, 28 286, No. 1112, Dierenwelzijn Motie van de leden Geurts en Bromet over een fatsoenlijke stopregeling voor de nertsenhouderij, proposed 10 June 2020, adopted 23 June 2020. See also the judgment by Hoge Raad, Uitspraak, 16 December 2016, Eerste Kamer 16/00921, LZ/EE.

7 Press conference on the statement of the Danish Prime Minister, of 4 November 2020. https://www.regeringen.dk/nyheder/2020/danmarks-minkbestand-aflives-grundet-mutation-af-coronavirus/ [Last accessed: 12 November 2020]; WHO Disease Outbreak News, SARS-CoV-2 mink-associated variant strain - Denmark, 6 November 2020. https://www.who.int/csr/don/06-november-2020-mink-associated-sars-cov2-denmark/en/ [Last accessed: 12 November 2020].

${ }^{8}$ International Agreement for the Creation of an Office International des Epizooties in Paris, with Appendix: the Organic Statutes of the Office International des Epizooties, of 25 January 1924 (57 LNTS 135); Organic Rules of the OIE, decided by the International Committee, of 24 May 1973. See also the General Rules, adopted by the Assembly, last revised in May 2013.

${ }^{9}$ The mandate is laid down in Art. 4 of the Organic Statutes (note 8): "The principal objects of the office are as follows: (a) To institute and to co-ordinate all research or investigation concerning the pathology or prophylaxis of contagious diseases of animals which call for international collaboration; (b) To collect and to notify to the Governments and their sanitary services the facts and documents of general interest concerning the progress of contagious diseases of animals and the means employed for fighting them; (c) To study the drafts of international agreements concerning veterinary police measures and to put at the disposal of the Powers signatory to these agreements the means of controlling the execution of such agreements."

${ }^{10}$ International Committee of the OIE, "Animal Welfare Mandate of the OIE", Resolution No. XIV of May 2002 (in OIE Doc. 70 GS/FR - PARIS, May 2002, pp. 31 et seq.); based on: OIE, Third Strategic Plan 2001-2005 (Paris, OIE 2002), p. 23 , point 6.

${ }^{11}$ OIE, 4th Strategic Plan (2006-2010), adopted by the International Committee at its 73rd General Session, 22-27 May 2005 , para. 19 (p. 7; emphasis added).

12 The last OIE Resolution, No. 31, was adopted during the 85th General Session, “Animal Welfare”, 85 GS/FR-Paris, May 2017. Besides, the OIE has regularly adopted specific resolutions which also mention animal welfare.

${ }^{13}$ The OIE is mentioned in the preamble and in Art. 3(4), Art. 12(3) and Annex A, 3(b) of the SPS-Agreement.

88 Derecho Animal. Forum of Animal Law Studies, vol. 11/4 
separate chapters entitled "Animal Welfare" in two so-called codes, the Terrestrial Animal Health Code and the Aquatic Animal Health Code (AAHC) ${ }^{14}$. These codes and their welfare chapters are currently in their 2019 edition. The Animal Health Codes are updated and revised annually, by decision of the World Assembly of OIE Delegates of all member states ${ }^{15}$. The codes are not international treaties, but only soft law with a recommendatory and aspirational character. Importantly, they are referenced both in domestic laws and in international law.

The codes provide criteria for assessing animal welfare ${ }^{16}$ but do not provide for precise standards such as cage size, pasture hours, or voltage minimums for electrocution. Moreover, and maybe inevitably so, the codes are replete of vague expressions and softeners. For example, they ask for "appropriate anaesthesia and pain management" in surgical sterilisation ${ }^{17}$; they say that transport containers should be "appropriate" to the animals' physiological and behavioural needs ${ }^{18}$; they prescribe that animal handlers should possess "adequate knowledge" 19 ; that animal body condition should not fall "outside an acceptable range" 20 ; feedstuff should have a "satisfactory quality" 21 ; that the handling of animals should not cause "avoidable stress" 22 and so on. Arguably, precise indicators or numeric standards would at present be futile given the huge global diversity of settings in which the animal welfare standards are to be applied.

The current work of the OIE towards improving the welfare of animals worldwide is a mixed blessing. The OIE Global Animal Welfare Strategy of 2017 does not call into question the various human uses of animals: "Animals may be kept as working animals, companion animals, for production of food, fibre and other animal products, for scientific and educational purposes and are transported and traded internationally. The OIE recognises all these purposes as legitimate, while carrying an associated ethical responsibility to ensure any such use is humane, as defined through the OIE's international standards for animal welfare, in recognition of the sentience of animals ${ }^{\text {“23 }}$.

So the justification given by the OIE for the rather lax restrictions placed on the human activity involving animals is both ethical and economic. The OIE mentions ethical responsibility but at the same time makes the business case in favour of moderate animal welfare measures. The OIE has concluded memoranda with a large number of business associations, ranging from the "International Dairy Federation" over the "International Meat Secretariat" to the "International Egg Commission" and numerous others ${ }^{24}$. These memoranda are probably an outer sign of a "close and symbiotic relationship with industry" 25 . The OIE's standard-setting processes seem to be strongly influenced by the animal processing industries and favour their profit interests ${ }^{26}$. There is a real risk of capture by the animal-processing industry.

On the other hand, the mere existence of universal animal welfare standards, however shallow, seems to be better than nothing. The codes' references to the five freedoms for animals, and to the three Rs of animal experimentation, and the ethical responsibility mentioned as guiding principles of the animal welfare chapter of the codes - all these concepts open a window for uplifting and continuously tightening the standards ${ }^{27}$. Also, the OIE strategy to regionalise action bears the possibility that some world regions, notably Europe, could act as forerunner on matters of animal welfare.

To conclude, the OIE animal welfare standards, their constant upgrading and their incorporation into the national laws of most states, into international trade law agreements, and into the work of other international organisations (such as the WTO, OECD, and FAO) may form conduits for the development of a

\footnotetext{
${ }^{14}$ The latest are: Sec. 7 "Animal Welfare", in the Terrestrial Animal Health Code (TAHC), 28th edition of May 2019; and Sec. 7 "Animal Welfare", in the Aquatic Animal Health Code (AAHC), 22nd edition of May 2019 (with four Chapters, i.a. on transport, stunning, and killing of farmed fish).

${ }^{15}$ The delegates are in most cases the heads of OIE members' veterinary authorities. The World Assembly meets at least once a year (Art. 2 of the General Rules of 2013). The General Session of the Assembly is held every year in May in Paris.

${ }^{16}$ Art. 7.9.4. TAHC 2019: "Criteria or measurables for the welfare of beef cattle"; Art. 7.10.3. TAHC 2019 (for broiler chicken); Art.

7.11.4. (for dairy cattle).

${ }^{17}$ Art. 7.7.6 TAHC 2019.

18 Art. 7.8.10 TAHC 2019

${ }^{19}$ Art. 7.9.5 TAHC 2019.

${ }^{20}$ Art. 7.9.5. TAHC 2019.

${ }^{21}$ Art. 7.9.5 TAHC 2019.

${ }^{22}$ Art. 7.1.5 TAHC 2019 No. 10.

${ }^{23}$ OIE, Global Animal Welfare Strategy 2017, Res. No. 31 (note 1212) 3.

${ }^{24}$ See for a list: https://www.oie.int/en/about-us/key-texts/cooperation-agreements/ [Last accessed 11 December 2020].

${ }^{25}$ OTTER, C. - O'SULLIVAN, S. - ROSS, S., Laying the Foundations for an International Animal Protection Regime, in Journal of Animal Ethics, 2 (2012) 53-72 (67).

${ }^{26}$ BOLLARD, L., Global Approaches to Regulating Farm Animal Welfare, in STEIER, G. - PATEL, K. (eds.), International Farm Animal, Wildlife and Food Safety Law (Cham 2017) 96: "The OIE standards are minimal, largely enshrining current industry practices".

${ }^{27}$ See in this sense KELCH, T., Globalization and Animal Law: Comparative Law, International Law, and International Trade (Alphen aan den Rhijn 2017) 307.
} 
body of global animal law which is gaining both depth and strength. The outbreak of a new zoonosis that is causing a hitherto unprecedented sanitary, social, political, and economic damage on a global scale underlines the need for an institutional hub to tackle zoonoses in all their dimensions. The OIE is the first port of call here. However, this organisation needs to become more transparent and more independent from industrial lobbying of pharmaceutical and food industries. Also, it needs to work together even more closely and routinely with other international institutions such as the WHO, the FAO, and the WTO. Such institutional cooperation is already under way. The collaboration of the three mentioned international organisations began in 2010 with a tripartite concept note that lays the basis for their "coordinating global activities to address health risks at the animal-human-ecosystems interfaces" ${ }^{28}$. Besides, further institutions and regimes should be directly involved, notably the WTO (especially via the Codex Alimentarius Commission and the SPSAgreement), the Convention on Biodiversity (CBD), and the Convention on International Trade in Endangered Species of Wild Fauna and Flora (CITES).

It is therefore laudable that the World Health Assembly, in its May 2020 meeting on the "Covid-19 response", requested the WHO General Director to apply the "One-Health Approach" and to continue to work closely with the OIE and the FAO in order "to identify the zoonotic source of the virus" which would allow "targeted interventions and a research agenda to reduce the risk of similar events occurring" ${ }^{\text {" } 29}$. The new institutional hub will need more resources and more competences. If the global institutions are not upgraded they will continue to be abused as an easy scape-goat by governments, as it has been done with the WHO during the pandemic ${ }^{30}$.

\section{COVID-19 and the Need for a Global Animal Law}

The need for a global animal law stems from the fact that virtually all aspects of (commodified) human-animal interactions (ranging from food production and food distribution over working animals and animal use in research to the breeding and keeping of pets) possess a transboundary, a global dimension.

\subsection{Problems of Global Nature and Proportions}

The industrialisation of meat, dairy, and fur production has massive environmental, climatic, social, and ethical consequences on a global scale. Animal food production is not only growing but is at the same time an increasingly global business. For example, the international trade in meat is growing more than the production as such. Also the trade in live animals is growing "exponentially" 31 .

The consolidation and globalisation of the slaughter industry contributes to this trend. Fewer and larger meat plants mean that animals must travel longer distances, even into other countries, for processing. The JFK airport in New York entertains one terminal just for animals ${ }^{32}$. In the Middle East in particular, animal imports have risen markedly: in 2016, Saudi Arabia alone imported nearly 1 billion US Dollar worth of live animals ${ }^{33}$.

The globalised animal business raises a range of additional problems for human society, for the environment, and for the planet. First, animal-based food (meat and dairy) is extremely resource-intensive. One third of the entire cereal crop and 75 percent of soy is fed to animals killed for meat instead of being eaten directly by humans ${ }^{34}$. The animals and their fodder need - besides the high amount of freshwater - a lot of space to grow. According to the Food and Agriculture Organization, land for animal grazing makes up 26 percent of the terrestrial surface ${ }^{35}$. Europe cannot provide the fodder for its animals. Fodder has to be imported. This is sometimes calculated as an "import of territory". The net "import of territory" for soy to Europe has been estimated to be 2.6 million hectares. Most of that territory is in South America where it is depriving local small scale agriculture of land.

Livestock significantly contributes to global warming. The International Panel on Climate Change

\footnotetext{
${ }^{28}$ FAO, OIE, WHO, The FAO-OIE-WHO collaboration, Sharing responsibilities and coordinating global activities to address health risks at the animal-human-ecosystem interfaces, April 2010. "This tripartite relationship envisages complementary work to develop normative standards and field programs to achieve One Health goals", 3.

${ }^{29}$ WHO, WHA, Covid-19 response, in Second plenary meeting, A73/VR/2, Doc. 73.1. of 19 May 2020 para. 9(6).

${ }^{30}$ Cf. the letter by US President Trump to the WHO Director-General of 18 May 2020, explaining the suspension of the financial contributions of the United States to the WHO, decided on 14 April 2020.

${ }^{31}$ PHILLIPS, C., The Animal Trade: Evolution, Ethics and Implications (Wallingford 2015) p. x.

${ }^{32}$ See http://arkjfk.com/.

${ }^{33}$ OSBORNE, H. - VAN DER ZEE, B., Live export: animals at risk in giant global industry, in The Guardian, 20 January 2020.

${ }^{34}$ Food and Agriculture Organization (FAO), Shaping the Future of Livestock (Rome, FAO 2018) 3 and 8. On soy: BRACK, B. GLOVER, A. - WELLESLEY, L., Agricultural Commodity Supply Chains Trade, Consumption Deforestation (Chatham House 2016) 25; FRAANJE, W. - GARNETT, T., Building Block Soy: Food, Feed, and Land Use Change (Food Climate Research Network, University of Oxford 2020) 4.

${ }^{35}$ FAO, Livestock's Long Shadow (Rome, FAO) 271; FAO, Shaping the Future of Livestock (note 34) 3 and 8.

90 Derecho Animal. Forum of Animal Law Studies, vol. 11/4
} 
recently confirmed that "Livestock on managed pastures and rangelands accounted for more than one half of total anthropogenic $\mathrm{N}_{2} \mathrm{O}$ emissions from agriculture in 2014" ${ }^{36}$. Looking at all these facts, it seems that agriculture must indeed be qualified as a "global emergency" 37 .

On the other hand, the industrialisation of agriculture, including the processing of animals, has much increased productivity and has led to cheaper market prices for food. In the developed world, the share of the household budget spent on food has therefore dramatically declined ${ }^{38}$. But the overconsumption of animalbased food, notably meat, leads to diet-related diseases in the Northern states ${ }^{39}$.

The excessive meat consumption additionally raises a problem of global social justice. Most of additional meat is produced in developed and rapidly developing countries, but not in the least developed countries. This means that the poorest human populations do not benefit from this production. To the contrary, unsustainable agricultural practices play a part in maintaining and even increasing food insecurity ${ }^{40}$. A Lancet Commission report of 2019 found that currently more than 820 million people have insufficient food, inter alia caused by excessive meat production for wealthy consumers ${ }^{41}$. Wildlife exploitation also raises global problems for humans. Illegal wildlife trade is emerging as a transnational organised crime, spanning from Africa to Asia. Wildlife trafficking is probably the fourth or fifth largest illegal global trade (besides the smuggling of narcotics, arms, persons, tobacco, and counterfeit consumer goods). The United Nations Office on Drugs and Crime (UNODC), World Wildlife Crime report of 2016 mentions more than 164000 seizures of wildlife products derived from nearly 7000 species, across 120 countries, for the reporting period between 1999 and $2015^{42}$. The illicit revenues from illegal trade in endangered wildlife products, including elephant ivory, rhino horns, and turtle shells, were estimated to amount to 7 billion to 10 billion US dollars annually (a much higher gain than the revenues from legal trade in non-fishery wild animal products), accompanied by illegal fishing worth roughly an additional 10 billion to 23 billion US dollars annually ${ }^{43}$. Major sites of trafficking are South East Asian countries, both on the supply and the demand side ${ }^{44}$. Wildlife poaching also finances armed conflict, notably in Africa ${ }^{45}$. And finally, the loss of genetic information through the extinction

\footnotetext{
${ }^{36}$ IPCC (SHUKLA, P.R. et al. (eds.)), Climate Change and Land: an IPCC special report on climate change, desertification, land degradation, sustainable land management, food security, and greenhouse gas fluxes in terrestrial ecosystems (New York, United Nations 2019) https://www.ipcc.ch/report/srccl/ [Last accessed: 12 November 2020] see "executive summary", 22. See also: FAO, Livestock's Long Shadow (note 35) 271.

${ }^{37}$ BRELS, S., A Global Approach to Animal Protection, in Journal of International Wildlife Law \& Policy, 20 (2017) 105-123 (113). ${ }^{38}$ For example, the average German household spent only 13,9 percent on food, in comparison to 36 percent in 1962/63. Data from 2011-2016: Statistisches Bundesamt, Wirtschaftsrechnungen. Laufende Wirtschaftsrechnungen, Einkommen, Einnahmen und Ausgaben privater Haushalte (Fachserie 15 Reihe 1) (Wiesbaden 2016) 18 et seq. Data before 2011: CZAJKA, S. - KOTT, K., Konsumausgaben privater Haushalte für Nahrungsmittel, Getränke und Tabakwaren 2003: Ergebnis der Einkommens- und Verbrauchsstichprobe 2003, in STATISTISCHES BUNDESAMT (ed.), Wirtschaft und Statistik Vol. 6 (Wiesbaden 2006), 631 et seq. ${ }^{39}$ See on the classification of the consumption of red meat as class $2 \mathrm{~A}$ (probably carcinogenic to humans) and of processed meat as class 1 (carcinogenic to humans) the International Agency for Research on Cancer (IARC) under the auspices of the World Health Organisation: WHO, IARC Monographs on the Identification of Carcinogenic Hazards to Humans (2019), https://monographs.iarc.fr/list-of-classifications.
}

${ }^{40}$ See on the negative impacts of factory farming on developing countries LEE, C. G., From Footnote to Forethought: Considering the Consequences of Large-scale, Industrialized Animal Agriculture in Developing Nations, in UC Davis Law Review, 25 (2019) $101-$ 138 (101 et seq., notably 127-129): "Exploitation of Developing Nations".

${ }^{41}$ WILLETT, W. et al., Food in the Anthropocene: the EAT-Lancet Commission on healthy diets from sustainable food systems, in The Lancet, 393 (2019) 447-492 (447 et seq.), available at: http://dx.doi.org/10.1016/S0140-6736(18)31788-4 [Last accessed 11 December 2020].

${ }^{42}$ United Nations Office on Drugs and Crime (UNODC), World Wildlife Crime Report: Trafficking in Protected Species (Vienna, UNODC 2016) 13, 29 and 31. The UNODC holds a database on World Wildlife Seizures ("World WISE database").

${ }^{43}$ WYLER, L. and SHEIKH, P., International Illegal Trade in Wildlife: Threats and U.S. Policy, in Congressional Research Service (2013).

${ }^{44}$ The reasons are rising wealth, a demand for animal products used in traditional medicine, the immense biodiversity in countries whose populations are poor, combined with a high degree of corruption (measured by corruption perception).

${ }^{45}$ See for the dimension of crime: Forum on Crime and Society $9(1,2)(2018)$, special issue "wildlife crime"; ABOTSI, K.E. et al., Wildlife Crime and Degradation in Africa: An Analysis of the Current Crisis and Prospects for a Secure Future, in Fordham Environmental Law Review, 27 (2015) 394-441 (394 et seq.); International Fund for Animal Welfare (IFAW), Disrupt: Wildlife Cybercrime (London 2018); KASSA, S. - COSTA, J. - BAEZ CAMARGO, C., Corruption and wildlife trafficking: exploring drivers, facilitators and networks behind illegal wildlife trade in East Africa, Basel Institute on Governance, Working Paper 30, 2019. See the latest resolution on the CAR (MINUSCA): UN SC Res. 2499 (2019) of 15 November 2019, Preamble 11th indent: "Condemning cross-border criminal activities, such as arms trafficking, illicit trade, illegal exploitation, and smuggling of natural resources, including gold, diamonds, wildlife poaching and trafficking (...) that threaten the peace and stability of the CAR and stressing the need for CAR authorities to finalise and implement, in cooperation with relevant partners, a strategy to tackle the illegal exploitation and smuggling of natural resources" and para. 41 (zero-tolerance policy on trafficking in natural resources or wildlife). See on the DR Congo (MONUSCO) UN SC Res. 2502 (2019) of 19 December 2019, para. 16: the illegal exploitation and trafficking of wildlife by armed groups and criminal networks supporting them "undermines lasting peace and development for the DRC"; also para. 45. In scholarship EICK, C., The German-Gabonese Initiative on Poaching and Illegal Wildlife Trafficking: Is there a role for the UN SC?, in German Yearbook of International Law, 59 (2013) 505-509. 
of species concerns all mankind.

To conclude, animal use contributes to problems of global nature and of global proportions: ecological damage, the extinction of species, human poverty and malnutrition, organised crime, and war.

\subsection{Further Factors Creating a Need for Global Animal Law}

Besides the globalised nature of the animal uses and their global social and ecological consequences, additional factors suggest that the regulatory response to animal welfare needs to be global ${ }^{46}$. Growing consumer attention in rich countries to animal welfare aspects in purchasing decisions is one factor. Consumers here expect lawmakers to take animal health and welfare seriously (and if only out of the consumers' concern for their own health). The resulting political pressure not only affects the regulation of domestic production but also the regulation of the importation of foreign animal products.

Relatedly, businesses seeking to export their animal products into states in which the consumers are concerned also pay more attention to animal welfare because they do not want to lose market shares. This also holds for the regulators in the countries of export if they want to support their trading industries. As a result, market forces pressure in the direction of a harmonisation of animal welfare standards.

The need for a global law approach to animal welfare becomes dramatic when we consider the most important feature of globalisation, namely capital and labour mobility and global supply chains in the animal industries. In such a globalised economy, legal loopholes are available for animal-related industries which might seize the opportunity to migrate away from stringent national animal welfare standards. Even if one country attempts to improve animal welfare standards, for example standards on the caging of livestock, slaughtering requirements, or protocols for animal experiments, one state cannot do so unilaterally if it wants the regulations to be fully effective. Significant parts of the affected sectors or branches of industry can escape stricter regulations by relocating ${ }^{47}$. To give one example, the dairy firm Fonterra of New Zealand was reported to establish intensive indoor dairy operations in China which confine thousands of dairy cows permanently without opportunity for grazing - practices which would be prohibited under the laws of New Zealand ${ }^{48}$.

Outsourcing is also widespread in the pharmaceutical industry and in research. Researchers move out to countries such as China where they can use animals much more liberally than in Europe and thus cause more suffering ${ }^{49}$. One example is the neuroscientist professor Nikos Logothetis, former director at the Max Planck Institute for Biological Cybernetics in Tübingen. He conducts brain research on apes, which earned him intense public critique, and even criminal charges. Logothetis then moved his controversial research to China. In new facilities at the university of Shanghai, his research team will be able to use - according to the press - "vastly more apes". With regard to animal welfare, Logothetis "intends to apply comparable standards as in Germany" ${ }^{50}$. I leave it to the reader to consider whether the new environment will be comparably apefriendly as Germany.

Obviously, the "leakage" of industries to cruelty-havens is bad for animal welfare. Such relocation to low-standard countries renders high national animal protection standards meaningless. Already the mere threat or expectation of outsourcing is bad for animals. Regulators are prone to bow to announcements that firms will move out, even if the prospect of outmigration may be only a convenient pretext in the political debate.

Individual countries usually try to keep or regain economically significant industrial sectors inside their borders. The states do so by supplying an attractively (permissive) legal environment. This may lead to stalling any further elevation of animal welfare standards, which is called a "regulatory chill". For example, the German political factions supporting the repeated postponement of phasing-out piglet castration without anaesthesia argued that an obligation to use narcotics would be a competitive disadvantage for the German farmers, that business would migrate, and that jobs would be lost in Germany ${ }^{51}$. The amendment to the animal

\footnotetext{
${ }^{46}$ SYKES, K., 'Nations Like Unto Yourselves': An Inquiry into the Status of a General Principle of International Law on Animal Welfare, in Canadian Yearbook of International Law, 49 (2011) 3-49 (4): "the entanglement of animals with transnational issues such as trade or environmental protection (...) suggest that the way human beings treat other animals indeed implicates international law". ${ }^{47}$ PETERS, A., The Competition between Legal Orders, in International Law Research, 3 (2014) 45-65.

${ }^{48}$ TURNER, P., Fonterra intensive dairy farming in China criticized, 3 February 2010.

https://www.rnz.co.nz/news/national/2116/fonterra-intensive-dairy-farming-in-china-criticised [last accessed: 25 March 2019]. See also BOLLARD, L., Global Approaches to Regulating Farm Animal Welfare, in STEIER, G. - PATEL, K. (eds.), International Farm Animal, Wildlife and Food Safety Law (Cham 2017) 88.

${ }^{49}$ SUEUR, C., La fuite de la recherche biomédicale sur les primates en Chine: quelles implications éthiques?, in Droit animal éthique \& sciences: Revue trimestrielle de la Fondation LFDA, 90 (2016) 19.

${ }^{50}$ WEHR, M., Flucht vor der Scheinmoral, Frankfurter Allgemeine Zeitung, 17 January 2020.

51 Bundestags-Drucksache 17/11811, Beschlussempfehlung und Bericht des Ausschusses für Ernährung, Landwirtschaft und Verbraucherschutz (10. Ausschuss) a) zu dem Gesetzentwurf der Bundesregierung - Drucksache 17/10572 - Entwurf eines Dritten Gesetzes zur Änderung des Tierschutzgesetzes, of 11 December 2012, p. 25. The prohibition was later again delayed until the end of 2020.
}

92 Derecho Animal. Forum of Animal Law Studies, vol. 11/4 
welfare act which was supposed to terminate the cruel practice by 2017 was therefore modified in parliament to give farmers more time to convert their production modes.

These examples have demonstrated that human animal interactions, notably the excessive economic exploitation of animals, create ethical, ecological, and social problems that affect humans and animals alike. And because animal use is embedded in the context of global capitalism, performed in transnational supply chains, and subject to a global regulatory competition, these problems have a global dimension. Global problems require global policy responses. Law is one component of such policies. Currently, however, there is a mismatch between the global dimension of the animal issue on the one hand, and almost exclusively national animal-related legislation on the other hand. This gap needs to be filled. It can be filled by an alignment of domestic laws, by adopting international treaties equipped with robust bodies that can develop secondary law, accompanied by transnational public-private co-regulation. This multidimensional regulatory response must grow from the bottom up, because international institutions have no chance of imposing responses on states top down. A domestic legal basis must therefore form the breeding-ground for international norms, and it must secure the operation of international law. This interaction is meant when speaking of a "global law"-approach ${ }^{52}$.

The COVID pandemic is a quintessential globalisation problem for at least three reasons: The spread is the consequence of the very high and fast transboundary mobility of persons and goods; interconnectedness and interdependence of societies makes them even more vulnerable not only directly for the virus itself but moreover for the effects of the virus on the economy; and (although states and their leaders strive for a certain degree of autarchy with regard to medical equipment) a complete decoupling from the transboundary production and supply chains will turn out to be impossible in the logic of global capitalism.

The above mentioned threat of relocation and the resulting neutralisation of animal-welfare measures in one country alone is starkly illustrated by the COVID-19 infection in the Dutch mink farms, mentioned above. The closure of the Dutch mink farms will most likely boost the farms in Denmark, Poland, and China (the three biggest mink fur producing countries), until import bans on mink products are issued by countries with market-power, or consumers altogether stop buying mink fur products, or - most effectively - a global prohibition is imposed.

Populations (both animal and human) will only be protected when the disease is overcome in the whole world. COVID-19 thus illustrates the need of global policy responses which include a global law approach. A global health approach (for animals and non-human animals) is just one building block.

\section{The Overlapping Consensus in Favour of Life and Health 5.1. Danger of Western Cultural and Legal Imposition}

The quest for global standards on animal welfare is in tension with respect for cultural diversity ${ }^{53}$. Conflicts over traditional, often religiously coloured practices, festivals, rites or simply habits involving animals are rampant in all multi-cultural societies. Practices range from animal sacrifice, to animal fights (bulls, dogs, cocks, and so on), and to eating those animals (dogs, whales, horses) that are adored as companions by others. Conflicts often involve indigenous populations. At this point, the critique of cultural and a concomitant legal imperialism arises. It has been said that the animal protection movement is "yet another crusade by the West against the practices of the rest of the world" 54 .

For example, in the 2019 CITES Conference of the Parties, Botswana (once again) proposed to put in place a mechanism for trade in ivory of elephant populations in Botswana, Namibia, South Africa and Zimbabwe. Botswana invoked the burden on governments forced to compensate communities affected by elephants, and the competition of elephants with other land uses ${ }^{55}$. This proposal was defeated in the CITES Conference of the Parties, notably with support of the United States and the EU which firmly oppose any legalisation of the ivory trade. Among the outvoted minority of states was the Caribbean state Antigua and Barbuda which noted that the rejection of Botswana's legalisation proposal "was inconsistent, and might be construed as racist" 56

The charge of racism and of cultural and legal imperialism is not trivial. There is a real risk that the

\footnotetext{
52 PETERS, A., Introduction: Global Animal Law in a Nutshell, in PETERS, A. (ed.), Studies in Global Animal Law (Heidelberg 2020) $1-13$.

${ }^{53}$ Seminally CASAL, P., Is Multiculturalism Bad for Animals?, in Journal of Political Philosophy, 11 (2003) 1-22.

${ }^{54}$ This is how the fictional character Thomas O'Hearn, "professor of philosophy of Appleton”, puts it (COETZEE, J. M., The Lives of Animals (Princeton 1999) 60).

${ }^{55}$ CITES, Eighteenth meeting of the Conference of the Parties, Geneva (Switzerland), 17-28 August 2019, Summary record of the eleventh session of Committee I, 22 August 2019 (CoP18 Com I. Rec. 11), rejection of Proposal CoP18 Prop. 11. See for the parallel proposal by Zambia CITES Doc. COP18 Prop. 10 and Chap. 1.

${ }^{56} \mathrm{Ibid}$., proposition 11, p. 3.
} 
protection of animals targets specifically minority practices such as Muslim ritual slaughter ${ }^{57}$, or indigenous seal hunt ${ }^{58}$, and indigenous whale hunting ${ }^{59}$. This is all the more problematic as these practices are in numerical terms insignificant in comparison to the majority's normalised massive use and killing of animals.

\subsection{Response}

Against this reproach of cultural and legal imperialism and of double standards I submit that this should not stymie international action in favour of animal welfare and even for animal rights.

First, we should not exaggerate cultural difference. The massive use of animals for human needs and the poorness of reflection on and justification of these practices in ethical terms is a shared feature of all cultures. Therefore, the quest for reducing and ending these abuses is very much a claim attacking all human cultures, and not singling out some cultures only.

The second response against the reproach of cultural hegemony is an argument of consistency. Animals are the "perpetual other". If we accept that - from a nonspeciecist view - animals are "Others" in a world of plural civilisations, the claim for respecting a "foreign" culture and for respecting the interests of the members of that cultural group would equally apply to animals ${ }^{60}$. On this premise, any claim of a human group to be entitled to victimise and sacrifice animals and the animal culture as a necessary component of their own cultural life is self-contradictory and must for this reason fail.

Thirdly, historical experience shows that the invocation of "culture" often has a pretextual character and merely cloaks other conflicts. For example, the European Union has addressed the challenge of cultural diversity with a reservation in its animal welfare mainstreaming clause. Art. 13 TFEU says that the Union and the implementing member states must "pay full regard to the welfare requirements of animals, while respecting the (...) provisions and customs of the Member States relating in particular to religious rites, cultural traditions and regional heritage" ${ }^{2}$. This cultural reservation or counter-obligation was included in the Treaty on the Functioning of the EU upon lobbying by Spain. The Spanish Ambassador boasted of having achieved this. He hired an eminent lawyer and invested in a couple of dinners and thereby: "iY así blindamos los toros!" 22 - he shielded bullfighting. A Spanish statute then legally defined bullfighting as part of the "cultural heritage" of Spain so that it fits exactly under the EU-exception ${ }^{63}$. This episode exemplifies how the invocation of culture and tradition can be instrumentalised in larger social conflicts about the distribution of wealth and power. Animals are only a token in such conflicts.

My fourth response to the reproach of cultural imperialism is that cultures do not unfold inevitably, as if according to a genetically defined pattern. Eating shark soup made from fins cut off live sharks, fox hunting with hounds, staging bullfights, and stuffing geese for foie gras are traditions just like prohibiting women from exercising certain professions was a tradition, or as not allowing women to drive a car, and is a tradition like mutilating the genitals of women. But simply because these are traditions they are not immutable, and are not worth protecting as such. Instead, morals, traditions, and also the law (all of which makes up culture) are made, practiced, and applied by human beings capable of learning. And therefore they can change. High level courts in several countries have forcefully made this point:

In Colombia, the Constitutional Court had to adjudicate on the constitutionality of the Colombian civil code's reform on animals as sentient beings. The Court said that "cultural manifestations are no direct expression of the Constitution" but result from social interaction. The court then fleshed out a "dialogical constitutionalism" which seeks to "strengthen a 'constitutional' culture that bans epochs of violence or disdain for the lives of others" (in which the court included animals). The Colombian court also said that such a constitutional culture seeks to "eradicate traditions of insensitivity for the other [non-human] inhabitants of

\footnotetext{
${ }^{57}$ Cf. CJEU, Liga van Moskeeën en islamitische Organisaties Provincie Antwerpen et al v. Vlaams Gewest, Grand Chamber Judgment of 29 May 2018, Case C-426/16; PETERS, A., Religious Slaughter and Animal Welfare Revisited, in Canadian Journal of Comparative and Contemporary Law, 5 (2019) 269-297.

${ }^{58}$ Cf. WTO panel, European Communities - Measures Prohibiting the Importation and Marketing of Seal Products, reports of 25 November 2013 (WT/DS400/R and WT/DS401/R); Appellate Body, European Communities - Measures Prohibiting the Importation and Marketing of Seal Products, reports of 22 May 2014 (WT/DS400/AB/R and WT/DS401/AB/R).

${ }^{59}$ FITZMAURICE, M., Indigenous Whaling and Environmental Protection, in German Yearbook of International Law, 55 (2012) 419-463.

${ }^{60}$ HORTA, O., Expanding Global Justice: The Case for the International Protection of Animals, in Global Policy, 4 (2013) 371-380 $(376,377)$.

${ }^{61}$ Art. 13 of the Treaty on the Functioning of the European Union (TFEU) of 13 December 2007, in force since 1 December 2009.

${ }^{62}$ ELORZA, F.J., Interview with L. Amiguet, in La Vanguardia, 2 June 1999. Also quoted in CASAL (note 53), p. 1. The Spanish lobbying success related to the identical text already enshrined in the 1997 Protocol.

${ }^{63}$ Ley 18/2013 of 12 November 2013 on the regulation of bullfighting as cultural heritage (Ley para la regulación de la Tauromaquia como patrimonio cultural), in Boletín Oficial del Estado, 272 (2013) Sec. I. Pág. 90737, No. 11837. See also Article 46 of the Spanish Constitution of 29 December 1978, as of 27 August 1992 on "national heritage". 
the territory" ${ }^{64}$. Cultural practices are therefore not shielded or immunised against legal regulation, "when it is necessary to limit or even suppress [these practices] because they run against values which society seeks to promote." Therefore, the legislator may prohibit cultural manifestations which involve the mistreatment of animals. The transformative dialogue about animal-abusive cultural practices - as invoked by the Colombian Constitutional Court - should not stop at a state's border. To quote the Barcelonan philosopher Paola Casal: " $[\mathrm{W}]$ hat we should celebrate, and struggle for, is the existence of a multitude of practices that are both diverse and good, not a varied collection of cruelties and crimes" ${ }^{65}$.

A fifth consideration in the debate about "cultural impositions" are double standards. At first sight, it seems hypocritical that Western populations criticise non-Western practices such as dog eating, whaling, seal hunt, bile bears, and tiger bone processing, when Europeans at the same time turn a blind eye to cruel factory farming and industrial slaughter in their own countries. The oppressed minorities and weaker populations on the globe might say "that the majority should leave minorities [and poor non-western nations] alone until they [the rich Westerners] clean up their own house." However, "[u]njust disadvantages in one sphere does not earn unjust advantages in another. Having endured racism and colonialism, subjects deserve justice and reparation from their oppressors, but they do not deserve to dominate women, animals, and nature" ${ }^{\prime 6}$. In other words, suffering from cultural and political oppression is no excuse for making other, yet weaker members of society - the animals - suffer in turn. Moreover, double standards can and should be terminated by levelling up, not by levelling down.

To conclude, cultural diversity is no blank check for animal abuse. Importantly, such abuse can be combated on the basis of a variety of different, also non-western cultures and traditions. The judgment of the Islamabad High Court of May 2020 illustrates this ${ }^{67}$. The Court's reasoning is firmly based in the Muslim tradition. It started by quoting Muhammad the prophet. After summarising the case law of a range of courts in other countries on animal rights, beginning with the habeas corpus for the apes Sandra and Cecilia in Argentina, the judgment contains a section on "The Treatment of Animals by various religions, particularly in the light of the injunctions of Islam" 68 . The Court wrote: "Be it Islam, Judaism, Christianity, Buddhism, Hinduism or any other religion, there is no dispute that 'life' is the most precious and superior creation of the Creator. There is consensus amongst all religions of the world that animals are 'sentient beings' i.e. able to perceive and feel" 69 . The Court then listed several verses in the holy Quran which explicitly relate to animals: "It is a natural right of an animal not to be tortured or unnecessarily killed because the gift of life it possesses is precious and its disrespect undermines the respect of the Creator ${ }^{\text {"70 }}$. As mentioned, the Court then found a constitution-based right of life of animals ultimately inspired by Islam and not resulting from a "Western" approach or imposition. This is an example of an overlapping consensus on an animal right to life which can be based on very different cultural, intellectual, and religious arguments.

\section{COVID-19 and the One Health Approach}

COVID-19 has dramatically brought to the fore the One Health approach ${ }^{71}$. This approach is defined in a recent UNEP publication as "the collaborative effort across multiple disciplines to attain optimal health for people, animals and the environment. It has emerged as a key tool for preventing and managing diseases occurring at the interface of human, animal and environment health." 72 The One Health paradigm came up in the aftermath of the 2003 outbreak of SARS (Severe Acute Respiratory Syndrome), a zoonotic disease likewise transmitted from bats. The veterinarian and activist Dr William B. Karesh seminally wrote that ,[g]lobal health will not be achieved without a shift from the expert-controlled, top-down paradigm that still dominates both science and medicine. A broader, more democratic approach is needed, one based on the understanding that there is only one world - and only one health"73.

Today, One Health is no longer just a buzzword but informs legal decision-making. For example, the Islamabad High Court mandated the release of zoo elephants with the argument that "the current pandemic crisis (...) has highlighted the interdependence of living beings on each other, (...) and (...) it has conspicuously

\footnotetext{
${ }^{64}$ Colombian Constitutional Court, sentence C-041 of 1 February 2017, para. 5.2. and 5.3 (my translation).

${ }^{65}$ CASAL (note 53) 22.

${ }^{66}$ KIM, C. J., Dangerous Crossings (Cambridge 2015) 196 (emphasis partly added).

${ }^{67}$ Islamabad High Court (note 1).

${ }^{68}$ Ibid., p. 41 et seq.

${ }^{69}$ Ibid., p. 47.

${ }^{70}$ Ibid., p. 60.

${ }^{71}$ See also BRAUN K., "COVID-19, people, and other animals”, Völkerrechtsblog, 12 November 2020.

${ }^{72}$ United Nations Environment Programme (UNEP) and International Livestock Research Institute (lead author Delia Grace Randolph), Preventing the Next Pandemic: Zoonotic diseases and how to break the chain of transmission (Nairobi, Kenya 2020$) 37$.

${ }^{73}$ KARESH W.B. - COOK, R.A., The Human-Animal Link, in Foreign Affairs 84 (2005) 38-50.
} 
brought the essence, meaning and significance of 'life' into the spotlight" 74 . This can be read as an implicit application of the One Health principle. Another example is the Convention on Biodiversity (CBD) COP decision of 2018 "Health and Biodiversity" 75 which was imbued by the One Health approach albeit without mentioning the word.

A One Health approach is inevitable facing the ongoing human-induced explosion of zoonoses. According to the Intergovernmental Platform on Biodiversity and Ecosystem Services (IPBES), "[a]n estimated 1.7 million currently undiscovered viruses are thought to exist in mammal and avian hosts. Of these, 540000 to 850000 could have the ability to infect humans"76. As the Lancet pointed out: "New zoonotic diseases are emerging and re-emerging at an exponentially increasing rate. (...) Not all zoonotic diseases become pandemics, but most pandemics are caused by zoonoses and they have become characteristic of the Anthropocene era" 77 . The reasons for the growing risk of zoonotic pandemics are the exponentially increasing anthropogenic changes of the earth system. These include land use and extraction, the clearing of land for farming and grazing, the intensive, industrialised livestock farming, and increased human encroachment into wildlife habitats ${ }^{78}$. Also deforestation frees microbes many of which have not yet been encountered by people. A key factor for the great acceleration of the spread of zoonoses is the exponential intensification of international travel and trade, key components of globalisation. UNEP sums this up as follows: "The frequency of pathogenic microorganisms jumping from other animals to people is increasing due to unsustainable human activities. Pandemics such as the COVID-19 outbreak are a predictable and predicted outcome of how people source and grow food, trade and consume animals, and alter environments"79.

Understanding the reasons for the proliferation of zoonoses is the key to combating them. A robust response demands the intensification and modification of the One Health approach. Inspiration can be found in a "solutions scan", published by a Cambridge-led international team of wildlife and veterinary experts in June 2020. It gives a list of options for reducing the risk of another pandemic ${ }^{80}$. The team mentions, inter alia, the following: "Reduce animal density both within and between farms;" "[t]ake measures to reduce stress in farmed animals including maximum permissible stocking densities and other basic welfare standards;" 81 "[i]ntroduce licencing or certification system for the transport of live animals or animal parts, to ensure hygiene and welfare standards are adhered to" 82 . The group finally mentions the options to "[p]romote the development and commercialisation of synthetic alternatives (e.g. synthetic fur, leather or lab-created meat)" and to "[i]nfluence consumer attitudes to increase acceptability of lower-risk substitute products (e.g. plants or synthetic substitutes for food, clothing or medicine instead of animal products, particularly those from highrisk species)" $"$. According to the IPBES, "[p]andemic risk could be significantly lowered by promoting responsible consumption and reducing unsustainable consumption of commodities from emerging disease hotspots, and of wildlife and wildlife-derived products, as well as by reducing excessive consumption of meat from livestock production" ${ }^{84}$. A geophysicist points out: "To prevent future pandemics (...) we must rethink our relationship with animals, and livestock in particular. The main upshot of this rethinking is the need to eat less animal-based food, including markedly reducing our consumption of beef" ${ }^{\prime 85}$. To sum up, COVID-19, including the episode of the mink culling, demonstrates that One Health must take not only wildlife but also livestock more decisively into its purview.

\section{Towards a Critical Global Animal Law}

COVID-19 illustrates how the law has up to now been (and will probably always be) profoundly ambivalent about animals. As a standard introduction to the field puts it: "Individual instances of gratuitous intentional cruelty against certain animals are banned, while institutionalized abuse of animals is allowed and

\footnotetext{
${ }^{74}$ Islamabad High Court (note 1).

${ }^{75} \mathrm{CBD} / \mathrm{COP} / \mathrm{DEC} / 14 / 4$ (2018).

76 IPBES, Workshop on Biodiversity and Pandemics, Workshop Report of 29 October 2020 (unredacted and not peer reviewed version)5.

${ }^{77}$ Lancet editorial, Zoonoses: beyond the human-animal-environment interface, 396 (July 4, 2020), 1.

${ }^{78}$ IPBES (note 76) 6.

${ }^{79}$ UNEP 2020 (note 72) 7.

${ }^{80}$ PETROVAN, S.O. - ALDRIDGE, D.C. - BARTLETT, H. et al., DOI 10.17605/OSF.IO/5JX3G. The "solutions scan" was initiated as a collaboration between BioRISC (the Biosecurity Research Initiative at St Catharine's College, Cambridge), Conservation Evidence based in the Department of Zoology, University of Cambridge, and numerous other researchers worldwide.

${ }^{81}$ Ibid., 33.

82 Ibid., 38.

${ }^{83}$ PETROVAN et al. (note 80) 42.

${ }^{84}$ IPBES (note 76) 6.

${ }^{85}$ ESHEL, G. "Pandemic leadership failures and public health", Commentary on Wiebers \& Feigin on Covid Crisis, in Animal Sentience 2020, 365.

96 Derecho Animal. Forum of Animal Law Studies, vol. 11/4
} 
often promoted under the law"86. The feminist legal scholar Catharine MacKinnon has warned that "[t]he good intentions of the powerful, far from saving the powerless, doom them. Unless you change the structure of the power you exercise, that you mean well may not save those you love. Animal rights advocates take note" 87 . The two cases mentioned in this paper exhibit how the law entrenches structural violence against animals, by allowing and protecting enterprises such as zoos and fur farms, mainly for the sake of economic profit of the humans running this business.

The said ambivalence pertains also to health law. Facing the virus, "[1]aw can serve as both an enabler and a barrier to global health, equity, and justice" $" 88$. In order to protect human health from a modest risk, 21 million minks were lawfully killed, without any consideration for the value of their lives to them. A modified and strengthened One Health approach might bolster an initiative to prohibit mink farming altogether, on a global scale. The endorsement of One Health as a legal principle would be the logical consequence of the insight, repeated by the Islamabad High Court, that "the right to life of humans is dependent on the welfare, wellbeing, preservation and conservation of all animal species" 89 .

Both episodes recounted in this essay, the Islamabad zoo case and the mink scandal, highlight not only the need but also the opportunities for a global and at the same time culture-sensitive approach. In both instances, the law has been changed by new legislation and court decision, for protecting animals better. In times of globalisation and digitalisation, knowledge about the cases easily spreads.

Global media bears new opportunities for disseminating knowledge about animals, and for shaping attitudes. Social media makes it easy to expose bad practices, to trigger scandalisation processes, and facilitate the formation of a global public opinion, for example on mink and other factory farms ${ }^{90}$. Mass mobilisation and viral campaigns are a gateway to change toward a direly needed, much deeper, much broader animal protection through law. The current crisis offers an opportunity for using this gateway. We might thus second the Islamabad High Court which opined that " $[t]$ he emergence of the dangerous infectious pandemic COVID19 has had a profound impact on the human race and its way of life. (...) The human race (...) has become helpless before an invisible and lethal virus. It appears that humans may have to consider changing their outlook and lifestyle for good." ${ }^{11}$ In our law-imbued world, this requires a change of the law. And one of the elements must be a critical global animal law.

\footnotetext{
${ }^{86}$ SHAFFER, J.E., An Introduction to Animals and the Law (London 2011) 192.

${ }^{87}$ MACKINNON, C.A., Of Mice and Men: A Feminist Fragment on Animal Rights, in SUNSTEIN, C.R. - NUSSBAUM, M. (eds.), Animal Rights: Debates and New Directions (Oxford 2004) 272.

${ }^{88}$ PHELAN, A.L. - ECCLESTON-TURNER, M. - ROURKE, M. - MALECHE, A. - WANG, C. Legal agreements: barriers and enablers to global equitable COVID-19 vaccine access, in The Lancet, September 7, 2020. https://www.thelancet.com/journals/lancet/article/PIIS0140-6736(20)31873-0/fulltext [Last accessed: 12 November 2020] 800-802 (800).

${ }^{89}$ Islamabad High Court (note 1) 60.

90 SINCLAIR, M., The Internationalization of Animal Welfare Standards, in THOMPSON, P.B. - KAPLAN, D.M. (eds.), Encyclopedia of Food and Agricultural Ethics (Dordrecht 2016) 1 (3).

${ }^{91}$ Islamabad High Court (note 1) 2.
} 